\title{
Vulnerabilities in Russian Agriculture to Climate Change
}

\author{
Stephen K. Wegren ${ }^{1}$ \\ ${ }^{1}$ Department of Political Science, Southern Methodist University, Dallas, TX, USA \\ Correspondence: Stephen Wegren, Department of Political Science, 3300 University Blvd, Southern Methodist \\ University, Dallas, TX 75275-0117, USA. Tel: 1-214-768-2523. E-mail: swegren@smu.edu
}

Received: December 17, 2020 Accepted: December 30, 2020 Online Published: January 6, 2021

\begin{abstract}
Russia's agricultural sector has experienced a significant rebound in production since 2000, becoming the leading wheat exporter in the world in six of the past agricultural years. Not only has Russia's role in the international food trade system become more important, as the world's population continues to increase Russia grain will become even more significant, especially to politically volatile regions where food riots have contributed to pressures for regime change. While analysts are cognizant of the effects of climate change and impacts on Russian agricultural production, little thought has been given to the pathways for a transition from industrial agriculture. The article identifies four vulnerabilities to the agricultural sector from climate change in the world and in Russia. The article discusses the dislocations that may occur during a transition from industrial agriculture. The final section considers alternative models for moving away from industrial agriculture, concluding that the market-driven approach in which private industry leads the transition by "going green" is the most politically viable in Russia.
\end{abstract}

Keywords: Russia, agriculture, climate change, industrial agriculture, food security

\section{Introduction}

During the past three decades there has been a tremendous increase in the awareness of the impact and consequences of climate change on social, economic, and political systems. Climate change has the potential to fundamentally reorder regional power hierarchies (Aspinall, 2011). It can also restructure the global power balance as some nations will benefit and others will decline. Within nations, climate change is and will continue to impact infrastructure, finance, and economic security (Hill and Martinez-Diaz, 2020). For this reason, the impact of climate change has concerned analysts in a wide range of disciplines (Stern, 2007). In particular, the link between climate change and the environmental impact on food production has resonated as environmental degradation clashes with greater demand for food (Brown, 2012). Speculation and rumors of regional shortages, poor harvests in grain-producing nations, or a decline in global reserves can set off price spikes in global commodity prices, which for food can be politically destabilizing (Barrett, 2013). Food price spikes led to protests and riots in dozens in countries in 2007-2008, and in 2010-2011 contributed to regime change in several Middle Eastern countries. Going forward, the global population will grow by two billion more people, totaling approximately 9-9.5 billion people by 2050 (Economic Research Service, 2017, p. 6). To feed a population of this size, the Food and Agriculture Organization (FAO) projects that the world's food production will need to rise by 60 percent (FAO, 2016, p. 1). In particular, the population of Sub-Sahara Africa is expected to double by 2050 (United Nations, 2019). Other regions such as the Middle East, Southwest Asia, and several countries in Southeast Asia will also experience high population growth to mid-century. These regions will need more food and are likely to increase demand for food imports.

\subsection{The Problem}

Russia's agricultural sector has experienced significant recovery during the past 20 years compared to the 1990s. The rebound in Russia's agriculture is important Russia has become a major producer and exporter of wheat. Russia as a grain exporter means that its grain adds to global food reserves. Since the 2014/15 agricultural year, Russia has led the world in wheat exports in all but one year. At present, Russia's wheat is exported to 138 different countries, including the crucially important but often volatile nations in the Middle East such as Egypt, Turkey, and Iran. Russia's grain aids food security in these and other nations. Second, as a result of higher grain production, Russia's role in the international food trade system has grown more significant. (An agricultural year is July 1 of one year to June 30 of the next year.) By volume, in the 2016/17 agriculture year Russia's wheat exports accounted for 14 percent of global wheat trade; in the 2017/18 agricultural year, Russia's wheat exports accounted for 18 
percent of global wheat trade; 19 percent in the 2018/19 agricultural year; and 18 percent in the 2019/20 agricultural year (author's calculations).

Finally, Russian grain is likely to play important to play an important role in feeding the additional people who will be added to 2050. Thus, the point is that nations, regions, governments, companies, and trading entities have a stake in how Russia's agriculture, and in particular its grain sector, performs.

At the same time that Russia's importance in the global food system is growing, it faces critical vulnerabilities from climate change. Russian agriculture has been industrialized since the 1930s. Russia's industrial sector is the country's main source of its greenhouse gas emissions, but the agricultural sector is also a significant contributor, accounting for 15-18 percent of greenhouse gas emissions and as much as 28 percent of emissions if food processing is included (Buzdalov, 2018, p. 78). For context, the agricultural sector contributed less than 3 percent of Russia's GDP in 2018 (Uzun and Shagaida, 2020, p. 409). Thus, Russia's agricultural sector contributes to climate change and in turn the effects of climate change have consequences for agricultural production. The impact of climate change affects Russia's grain production which in turn will influence both Russia's role in the global food trade system and the amount of grain that Russia is able to make available to regions where populations are growing and demand for food is increasing.

\subsection{Relevant Literature}

Russia is in a unique position because parts of it may benefit from climate change as northern regions experience longer growing seasons. Further, the melting of Arctic ice is opening trade routes that allow for shorter travel time and cheaper transportation, which has led to a significant increase in the volume of traffic and tons of merchandise being shipped through the Arctic (Barents Observer, 2019; Saul, 2020). The melting of Arctic ice has set off a scramble to discover and claim new energy resources (LePan, 2020). It has also led to new efforts to militarize the Arctic (Shea, 2019). Russia benefits from climate change in that the opening of Northern trade routes through previously frozen water enables Russia to charge transit fees through its protected waters (Wegren, Nikulin, and Trotsuk, 2021, 203).

Scholars have been sensitive to the effects of climate change and the impact on Russian agricultural production (Dronin and Kirilenko, 2008; Svetlov, et al., 2019). The Russian government adopted a national action plan on climate change in January 2020 (Radio Free Europe, 2020). However, little thought has been given to the pathways for a transition from industrial agriculture. Neither policymakers nor analysts have not articulated what the transition from industrial agriculture may look like or the vulnerabilities that arise in that transition. The purpose of this article, therefore, is to think broadly about the relationship between climate change and Russia's transition from industrial agriculture. This article discusses four specific vulnerabilities to climate change in Russia's agricultural sector and the dislocations that may occur in an attempt to transition away from industrial agriculture. The final section of the paper considers alternative models for moving away from industrial agriculture and the prospects for each.

\section{Method}

The methodology for the article is interdisciplinary with the state as the unit of analysis. The source material consists of secondary sources in English; Russian language journals, newspapers, and online sources; Russian statistical books; and Russia's 2016 agricultural census.

\section{Discussion}

\subsection{Vulnerability Number 1: Grain Production}

Agricultural production is highly sensitive to climate change (Sobolev, 2020a, p. 64). Russia has experienced relatively good weather in recent years that has led to six successive grain harvests above 100 million tons for the first time in the post-Soviet period. But Russia cannot escape weather anomalies completely, and a severe drought occurred in 2010 with less severe droughts in 2012, 2013, 2015, 2017, 2018, 2019, and 2020. So far, Russia's size has served it well in that if one region of the country suffers from drought or flood, other regions can compensate. In the post-Soviet period, Russia's worst weather anomaly was in 2010, when it lost one-third of its grain harvest due to extreme heat and drought, leading to the cancellation all wheat export contracts from August 2010 to July 2011 (Wegren, 2011). In that year, more than 43 regions within Russia were affected by heat and drought, leading to agricultural losses of more than R41 billion. Russia's cancellation of its wheat contracts contributed to food price spikes among Middle East nations which were major purchasers of Russian wheat. During the export ban, the patterns and flows of domestic grain trade changed significantly away from the main export terminals on the Black Sea (Götz, Djuric, and Nivievskyi, 2016). In 2020, drought and flooding affected 12 regions with a loss of R25 billion to agriculture through October. 
A second economic effect of climate change is lower volumes of grain production in traditional grain-growing regions and more grain production in non-black earth regions (Svetlov et al., 2019, p. 411). If Russia's south, which on average accounts for almost 40 percent of Russia's grain production, begins to produce less grain due to climate change, Russia's entire agricultural profile could potentially shift from being a major grain exporter to becoming a net importer as during the Soviet era, thereby putting stress on global grain supplies. The entire structure of grain production would change, and non-black earth regions would become relatively more important.

Generally, non-black earth regions have lower yields per hectare and are less suitable for agricultural production due to soil composition, forests, or air temperature. Two of Russia's western regions that have non-chernozem soil - the Central and Northwest Federal Districts - are characterized by marginal farm land that lacks the natural fertility of Russia's south (Ioffe and Nefedova, 2000; Ioffe and Nefedova, 2004). The Central Federal District produces less than 10 percent of Russia's grain. Further, non-black earth districts have experienced significant land abandonment, rural depopulation, and farm closures during the past 30 years which have led to demographic "black holes" (Ioffe, Nefedova, Zaslavksy, 2006) throughout the non-black zone that reflect insufficient human capital in addition to deficiencies in social capital and physical infrastructure (Ministerstvo, 2019). It would be a monumental, and expensive, task to reverse demographic trends in Russia's non-black earth zones, if it could be accomplished at all.

If Russia's grain production were to depend more on non-black earth regions, Russia's role in the international food trade system would likely change. The country would undoubtedly lose its position as the world's top wheat exporter, a spot it has held in all but one year since 2014. Grain production in non-black earth regions would become much more expensive with less to show for it. Given the fact that federal policymakers have indicated that productive and profitable farms are to receive the most state support, it is not clear how directing more resources to marginal agricultural areas would play out.

As Russia's south becomes hotter, drier, and less productive, Russia's grain exports could decrease which in turn would affect world grain supplies. At a time when the global population is growing and the need for more food production is greater, global reserves would decline and the entire world would be much more vulnerable to spikes in food prices if drought or other weather conditions affected production in the United States, Canada, Australia, or Brazil. There are also international political implications. During 2010-2012, several grain-producing countries curtailed their grain exports which in turn caused global grain shortages and a spike in global commodity prices. Russia's grain cutoff of grain exports in 2010-2011 to the Middle East contributed to the Arab Spring and the collapse of regimes in Tunisia and Egypt, and the outbreak of civil war in Syria (Lybbert and Morgan, 2013). Today, among Middle Eastern nations, Turkey, Egypt, Iran, Saudi Arabia, Morocco, and United Arab Emirates are buyers of Russian grain, and Syria receives food assistance from Russia.

\subsection{Vulnerability Number 2: Food Insecurity}

A second vulnerability from the effects of climate change is the prospect of rising food insecurity within Russia. The rebound in Russia's agricultural sector since 2000 has improved the country's food security as average consumption levels have increased. A well-fed workforce aids economic productivity. Further, ample domestic food supplies lessen the likelihood of spikes in food prices that have been shown to be destabilizing in authoritarian countries (Barrett, 2013). The danger from climate change is witnessed by the warning from Russia's Ministry of Natural Resources that climate change could bring drought and mass hunger to much of the country (Russia is warming, 2019). Russia's geographical diversity places the country in better condition than small countries with monocultural agriculture, but Russia's food production in certain regions will be impacted. In particular, climate change is likely to have the most pronounced effects on agricultural production in Russia's south and west (Economist Intelligence Unit, 2019, p. 6). In Russia's south, most of the nation's food is produced, and 79 percent of Russia's population lives on the western side of the Urals. To reduce the consequences of production failure from any one region, the Ministry of Agriculture is investing in land reclamation to bring at least 4 million hectares of previously abandoned and unused land into production by 2025 (Minsel'khoz, 2020a). For context, Russia devoted 80 million hectares of agricultural land to grain production in 2020. But the problem is that land reclamation is costly and reclaimed land is often low yield, which means that basic food production will be more expensive and less productive.

Food security is vulnerable to climate change in two ways. The first way is shortfalls in production that can lead to shortages. The Russian government has shown great sensitivity to domestic food supplies and has periodically restricted grain exports to ensure sufficient domestic supplies, and in 2020 compensated milling companies for the rising price of wheat. The second vulnerability is rising food prices. Weather anomalies have been shown to lead to an increase in food prices (Sobolev, 2020b). The threat of rising prices is greatest for low-income groups. In 
2019, Russia had 18.1 million people who lived below the official poverty line, equal to 12 percent of the population. Of those 18 million people who live below the poverty line, 52 percent lived in rural areas. The poor in Russia consume less protein, fat, and carbohydrates than non-poor households; and the poor consume about 23 percent fewer calories per day than the non-poor (Rosstat, 2020, p. 66). In the second quarter of 2020, people in Russia's very lowest income decile spent more than one-half of their disposable income on food. The point is that the poor do not have a lot of financial flexibility: they already eat less and spend more of their income on food, so if food prices rose due to the effects of a weather anomaly they would be severely hurt.

Even though the rural population has the opportunity to grow some of their own food on their household gardens, they too are affected by weather anomalies. Drought means higher prices for animal feed. It also means higher retail prices for processed products that are purchased such as meat, milk, cheese, and other dairy products. In rural areas, there are fewer food stores and less competition, so consumers have less choice and prices may be higher due to transportation costs and the lack of competition. Rural dwellers already have about one-third less disposable income than urban residents and spend a higher percentage of their budget on food. Rural dwellers whose income is just above the poverty cutoff would probably be thrust into poverty if food prices rose significantly. A sizeable rise in Russia's poverty rate would put pressure on the government to provide financial assistance at a time when revenue from oil exports may be declining as other countries transition away from fossil fuels. The combination of those events could be politically explosive.

Another dimension of food insecurity concerns Russia's grain export policy. Russia's federal government has tried to protect domestic food security by limiting food exports. The government is concerned that with a weak ruble, too much grain will be exported and thereby lead to shortages within Russia. Although Russia reaped its second largest harvest in 2020, more than 131 million tons, the Ministry of Agriculture announced that it would begin export quotas on wheat during the second half of agricultural years (January-June). For the 2019/20 agricultural year the export quota was 7 million tons, starting in April 2020. The quota for the 2020/21 will be 17.5 million tons starting February 15, 2021 (Shokurova, 2020b). In December 2020, the ministry also announced that it would impose an export tariff on wheat, which had been reduced to zero in 2019. The tariff equals 25 euro per ton within the quota and 50 percent of the custom value but not less than 100 euro per ton outside the quota. The tariff will be effect from February 15 to June 30, 2021 (TASS, 2020). The purpose is to avoid price spikes for food and protect domestic food security.

\subsection{Vulnerability Number 3: Labor Dislocation}

A third vulnerability is labor dislocation that may occur on industrial farms where employment could be curtailed in response to worsening effects of climate change. Russia's rural working class is relatively small compared to the industrial working class, but the downstream effects of reduced employment could be detrimental to rural communities and villages where farm employment is still significant. According to Russia's 2016 agricultural census, 1.23 million persons were employed in agricultural production on farm organizations, of whom 1.13 million were permanent workers (Rosstat, 2018, pp. 198-99). The top five food producing regions in Russia account for about 26 percent of farm employment so they would experience the most labor dislocation from climate change (Rosstat, 2018, pp. 198-200).

The industrial working class may also experience labor dislocation from lower demand for inputs used by industrial agriculture, for example the manufacture of farm machinery and equipment, which in recent years has been increasing as the government tries to recover from the demechanization of the 1990s (Minsel'khoz, 2020b). To give a sense of the magnitude, two million people are employed in the food processing industry, which has more than 22,000 enterprises with 30 different branches that produce more than 60 types of products for retail sale (Ekspotsentr, no date). Tens of thousands of people are employed in manufacturing and machine building used in agriculture. An estimated 11 million people are employed in throughout the retail food industry (Wegren, Nikulin, and Trotsuk, 2021, p. 208). The point is that jobs and economic growth are linked to the industrial agricultural system, and either a collapse of industrial agriculture due to climate change or a transition away from industrial agriculture is likely to bring employment dislocation to many people.

\subsection{Vulnerability Number 4: Financial Dislocation}

Climate change and efforts to respond to it by curtailing industrial agriculture are likely to bring financial dislocation. In particular, potential lost tax revenue to federal and regional budgets from a decline in farm production could equal several hundred billion rubles annually. To illustrate, in 2019 taxable food-producing entities - farm enterprises and private farms - produced agricultural commodities worth R3.42 trillion. Russia's value added tax is 20 percent, so potential lost tax revenue equals as much as R680 billion. I acknowledge that this is a simplistic calculation because like most tax codes around the world there are exemptions and exclusions. The 
larger point is that potential lost tax revenue equals several hundred billion rubles. Of course, agricultural production will not go to zero, but one can calculate the impact of a 20 percent, 30 percent, or 40 percent decline on the value of output due to climate change or transition from industrial agriculture.

In this financial context, agroholdings play a special role in Russia's agriculture. Agroholdings are vertically integrated businesses that engage in many different types of economic activity from food production to processing to retailing. An agroholding consolidates several large farms within a common ownership or control structure. Some agroholdings have farms encompassing hundreds of thousands of hectares; these farms generate considerable tax revenue for regional governments based on their earnings. In 2019, Rusagro had gross earnings of nearly R139 billion; and Cherkizovo had a net profit of nearly R7 billion. Overall, agroholdings have enormous financial and economic power. According to Russian Academicians Uzun and Shagaida, agroholdings accounted for about 54 percent of all production, 56 percent of gross earnings, and more than 41 percent of total employment among Russia's agricultural enterprises in 2016 (Uzun and Shagaida, 2020, p. 427). Agroholdings are also important because animal husbandry production is highly concentrated in the top 20 or 25 agroholding companies. In 2018, for example, the top 20 agroholdings accounted for 56 percent of pork production and two-thirds of poultry meat (Wegren, Nikulin, and Trotsuk, 2021, p. 68). This trend in Russia resembles the oligopolies in the seed, chemical, animal breeding, farm machinery building, the grain industry, food processing, and food retailing in the United States whereby the top four companies control more than 50 percent of market share (Lengnick, 2015, pp. 323-24).

Agroholdings also contribute to regional economies in other ways. Agroholdings are a major driving force in the modernization and digitalization of Russian agriculture. They invest heavily in advanced machinery and technology, and that in turn creates demand for jobs and high-tech products. According to its website, the agroholding Miratorg (www.miratorg.ru) has invested more than R200 billion into Russia's agricultural sector, more than any other company. Those investments create local jobs in food processing, transportation and wholesale distribution, and retailing. Employees in turn pay rent, taxes, go shopping, and buy large ticket durables such as cars and household goods. The vulnerability arises from the fact that a transition from industrial agriculture would be financially devastating for regions where agroholdings' footprint is large, for example, in Belgorod oblast where agroholdings or their subsidiaries account for 90 percent of food production (Epshtein, Holbrook, and Wandel, 2013).

A second financial dislocation will affect regional economies where industrial agriculture accounts for a substantial percentage of regional GDP. Not only will regional GDP drop from a decline in industrial agriculture, the ripple effects will impact downstream employment, household income, household spending, and standards of living, particularly in Russia's southern regions were agriculture is strong. To illustrate, in 2018, agricultural production accounted for about 3 percent of Russia's GDP. However, agricultural production as a percentage of regional GDP was much higher in the nation's top-five agricultural regions. In 2018 (the latest data available as this article is written), agricultural output as a percentage of gross regional product equaled 16 percent in Krasnodar krai; 19 percent in Rostov oblast; 11 percent in the Republic of Tatarstan; almost 29 percent in Belgorod oblast; and 22 percent in Voronezh oblast (author's calculations from Rosstat, 2019, pp. 708-09). These are the regions that produce the bulk of food that feeds the nation and creates surpluses for export. If agricultural production declines due to climate change or from efforts to transition away from industrial agriculture, including large animal husbandry farms, rural unemployment will spike, food security will suffer, and surpluses for export will disappear. In 2019, Russia earned nearly \$25 billion USD from food exports according to the Federal Customs Union. Despite the global pandemic, during 2020 Russia exported agri-food products valued at \$28.9 billion USD through December 27, 2020 according to the Ministry of Agriculture.

\subsection{What is to be Done?}

Scientists predict that the effects of climate change will become more severe in the future. Once in a lifetime natural catastrophes will become annual events (Oppenheimer, 2020). The Russian government is currently more interested in managing the symptoms of climate change as they affect agriculture - for instance through expanding crop irrigation and subsidizing the crop insurance system - than addressing root causes such as industrial agriculture. More broadly, many policymakers in Russia continue to be undecided whether global warming is actually a bad thing. Warmer air temperatures will extend the growing season in Russia's northern regions. Some areas will benefit from a later beginning to winter, thereby allowing more time to complete the harvest. Moreover, increased carbon dioxide in the atmosphere makes crops grow more quickly but reduces the nutrient density in some crops such as rice (Savage, 2019). The deep roots of industrial agriculture in Russia's economy suggest that food policies will continue to be reactive rather than proactive with regard to the introduction of widespread sustainable agricultural practices. 
Eventually, climate change may necessitate a radical restructuring in Russia's agri-food system. Reducing greenhouse emissions from agriculture requires moving away from industrial agriculture. Russia will have to adjust the way it produces, transports, and distributes food. Russia is not alone in facing the socioeconomic dilemmas that arise when contemplating replacing the industrial agricultural system, a task that faces the developed world in general (Sachs, 2015). However, the costs and consequences (both economic and political) of moving away from industrial agriculture make that transformation formidable. What, then, are options for the future? I examine five alternative models for the transition to away from industrial agriculture, models that help to mitigate greenhouse gas emissions from industrial agriculture, and address the vulnerabilities to climate change while supporting food security. These models pay particular attention to value change and the role of the state as variables.

The first option is the market liberal model. Market liberals maintain that sustainable development is in the interest of business, and therefore the role of the state is to "unleash the power of the invisible hand of the market" to drive economic growth, and foster innovation and efficiency (Clapp and Dauvergne, 2011, pp. 229-32). With regard to agriculture, in this model business will adopt sustainable practices because it is in their interest to do so. This model entails moderate value change by consumers, a more significant value by business, and retains a status quo role for the state.

A second is the institutional model. Institutionalists share many of the same assumptions as market liberals but add an important caveat. According to the second model, moving toward sustainability cannot depend on the market alone to guide decisions. Institutions (rules, laws, regulations, policies) need to channel action toward sustainability and to guide policy to the desired outcomes. Institutions are state-defined and thus this model implies more intervention in policy by national and local governments. This model implies that state interests remain relevant and those interests may parallel business interests, but business interests should not be the sole guiding principle (Clapp and Peter Dauvergne, 2011, pp. 233-36). This model entails minimal value change for consumers, a moderate change in values by policymakers, and a significant role for the state.

A third is the bioenvironmental model, which is premised on the belief that mankind is the primary threat to the earth's ecology. Humans' drive to conquer nature has despoiled the earth and its resources. According to this model, the earth is beyond its carrying capacity and therefore it argues that population growth must be slowed or even stopped. Given the fact that most of the developed world has fertility rates that are below replacement level, a reduction in population growth implicitly is directed at Asia, the Middle East, and Sub-Sahara Africa, all of which have fertility rates well above replacement (with the exception of China). This model advocates a new political economy that must respect the biological limits of the earth; a new sustainability ethic needs to move nations to a steady-state economy which in agriculture means moving away from industrial agriculture (Clapp and Dauvergne, 2011, pp. 237-39). This model's policies are guided by what is good for the environment and the planet rather than by business or state interests. It entails substantial value change for consumers and policymakers; and it implies a significant role for the state, but that role should work toward goals and policies that are earth-friendly.

The fourth is the social green model, which advocates social and environmental justice. The model rejects globalization and all that it rests on and calls for the "individualization of responsibility" for environmental choices such as green consumption and recycling. In addition to putting responsibility for environmental choices on individuals, this model looks to collective action to downgrade existing global institutions, change the international trading system, cancel debts of developing country, and localize economies (Clapp and Dauvergne, 2011, pp. 24144). Inherent to these changes is a rejection of industrial agriculture, which as noted above not only harms the environment but causes social injustice. This model entails extensive value change on the part of consumers and policymakers and a fundamentally different role for the state whose participation in global institutions will be significantly downgraded.

The fifth model is based upon community action, which somewhat similar to the fourth in that initiatives must be local, from the bottom up and not top-down. But the fifth model is different in that it eschews collective action and does not advocate global changes in institutions, trade, and debt. The community action model focuses specifically on local action. A prime example of this model is Community Supported Agriculture in the United States where community action is helping small family farmers and reducing the environmental footprint of farming. Community Supported Agriculture is a system that helps farmers by increasing direct sales to consumers, reduces the number of steps between farmer and consumer, and makes food production profitable (Kleppel, 2014, pp. 9199).

In the industrial agricultural system, food production is often not profitable for the small producer, who is paid less than the cost of production by companies that control processing. Farmers remain in business only because of government subsidies and thus are vulnerable to political choices. But the low-price-high-subsidy system is a 
pathway to chronic debt or bankruptcy. Community Supported Agriculture, in which consumers see the value and quality that farmers bring to their sustainably produced food, pays family farmers a fair price and allows those who use sustainable practices to remain in business. This model entails moderate value change by consumers and policymakers and deemphasizes the role of the state in agriculture by implying movement toward sustainable farming. In the United States, Community Supported Agriculture parallels traditional supply chains but does not replace them; the two exist in parallel.

Models one, two, and five represent change in a food system; models three and four are more radical and represent change of a food system. Russia remains a state-led system in many respects and is unlikely to adopt models three or four because it is not realistic to expect the state to adopt policies that diminish the power of the state. Instead, some permutation of models one or two is possible in Russia. Although the federal government remains committed to industrial agriculture, the institutional model (two) is less likely. Between models one and two, the market-led model (one) is more likely if business comes to see "going green" is in its interest. Model five, which in some ways is the least challenging to actors who are vested in the current system, requires that Russia develop and strengthen local initiatives for sustainable agriculture. This is not an impossible task, but local social movements in rural areas are weak and often support the status quo (Mamonova and Visser, 2014, pp. 491-516).

Finally, there are vast regions in Russia where local food production cannot feed the population such as in northern regions and areas above the Arctic Circle, and the Far East (Shcherbakova, 2020). These regions depend on food "imports" from other parts of the country, although efforts are being made to expand vegetable production in some northern and Far Eastern regions by building greenhouse complexes in order to increase self-sufficiency. For example, in 2020 Russia's Ministry of Agriculture transferred R10 billion to subsidize the construction of greenhouses on 30 hectares of land in the Russian Far East, with the goal to reduce vegetable imports to 10 percent of demand in coming years (Shokurova, 2020a). Results will be known in a few years, but for now some regions are simply ill-suited to adapt to a sustainable agricultural system due to climatic, geographical, and unsuitable natural conditions.

\section{Conclusion}

The world already depends upon Russian grain and will become more dependent as the global population increases to mid-century. Russia's agricultural system, similar to other developed states, is based upon industrial agriculture, a system that scientists and policy analysts understand is not sustainable in an era of climate change. The transition away from industrial agriculture exposes societal vulnerabilities. Within Russia, the extent of any transition will vary by a region's ability to ensure its food security. As Russia navigates between moving away from industrial agriculture and what is politically possible, it is clear that the road will be neither easy nor short, and that its agricultural sector will remain vulnerable to the effects of climate change. These vulnerabilities will in turn impact global grain markets and reserves.

\section{References}

Aspinall, R. (2011). Toward a Regional and World Geography under a Changed Climate. Eurasian Geography and Economics, 52(1), 1-11. https://doi.org/10.2747/1539-7216.52.1.1

Barents, O. (2019). Ice on Russia's Northern Sea Route Has Disappeared, Opening up Arctic Sea Lanes. Retrieved from August 29, 2019 https://www.themoscowtimes.com/2019/08/29/ice-on-russias-northern-sea-route-hasdisappeared-opening-up-arctic-shipping-lanes-a67067

Barrett, C. B. (2013). Food or Consequences: Food Security and Its Implications for Global Sociopolitical Stability. In C. B. Barrett (Ed.). Food Security and Sociopolitical Stability (pp. 1-34). Oxford: Oxford University Press.

Brown, L. R. (2012). Full Planet, Empty Plates: The New Geopolitics of Food Scarcity. New York: W. W. Norton and Co.

Buzdalov, I. (2018). Sovremennoe polozhenie v sel'skom khoziaistve Rossii: Sistemnyi agrarnyi krizis prodolzhaetsia. Obshchestvo i Ekonomika, 3, 75-92.

Clapp, J., \& Dauvergne, P. (2011). Paths to a Green World: The Political Economy of the Global Environment. Cambridge, MA: MIT Press.

Dronin, N., \& Kirilenko, A. (2008). Climate change and food stress in Russia: what if the market transforms as it did during the past century? Climate Change, 86, 123-150. https://doi 10.1007/s10584-007-9282-z

Economic Research Service. (2017). Progress and Challenges in Global Food Security, Bulletin 175. Washington, DC: United States Department of Agriculture.

Economist Intelligence Unit. (2019). Resilience to climate change? A Report by the Economist Intelligence Unit. 
London: Economist Intelligence Unit.

Ekspotsentr. (n.d.). Statistika pishchevoi promyshlennosti Rossii. Retrieved from https://www.agroprodmashexpo.ru/ru/articles/pishchevaya-promyshlennost-rossii/

Epshtein, D., Hahlbrock, K., \& Wandelm, J. (2013). Why are agroholdings so pervasive in Russia's Belgorod oblast'? Evidence from case studies and farm-level data. Post-Communist Economies, 25(1), 59-81. https://doi.org/10.1080/14631377.2013.756673

FAO. (2016). Climate change and food security: risks and responses. Rome: FAO.

Götz, L., Djuric, I., \& Nivievskyi, O. (2016). Regional Price Effects of Extreme Weather Events and Wheat Export Controls in Russia and Ukraine. Journal of Agricultural Economics, 67(3), 741-763. https://doi.org/10.1111/1477-9552.12167

Hill, A., \& Martinez-Diaz, L. (2020). Adapt or Perish. Foreign Affairs, 99(1), 107-117.

Ioffe, G., \& Nefedova, T. (2000). Areas of Crisis in Russian Agriculture: A Geographic Perspective. Post-Soviet Geography and Economics, 41(4), 288-303. https://doi.org/10.1080/10889388.2000.10641142

Ioffe, G., \& Nefedova, T. (2004). Marginal Farmland in European Russia. Eurasian Geography and Economics, 45(1), 45-59. https://doi.org/10.2747/1538-7216.45.1.45

Ioffe, G., Nefedova, T., \& Zaslavsky, I. (2006). The End of Peasantry? The Disintegration of Rural Russia. Pittsburgh: University of Pittsburgh Press.

Kleppel, G. (2014). The Emergent Agriculture: Farming, Sustainability and the Return of the Local Economy. Gabriola Island, Canada: New Society Publishers.

Lengnick, L. (2015). Resilient Agriculture: Cultivating Food Systems for a Changing Climate. Gabriola Island: New Society Publishers.

LePan, N. (2020). The final frontier: how Arctic ice melting is opening up trade opportunities. Retrieved February 13, 2020 from https://www.weforum.org/agenda/2020/02/ice-melting-arctic-transport-route-industry/

Lybbert, T. J., \& Morgan, H. R. (2013). Lessons from the Arab Spring: Food Security and Stability in the Middle East and North Africa. In C. B. Barrett (Ed.), Food Security and Sociopolitical Stability (pp. 358-380). Oxford: Oxford University Press.

Mamonova, N., \& Visser, O. (2014). State marionettes, phantom organisations or genuine movements? The paradoxical emergence of rural social movements in post-socialist Russia. The Journal of Peasant Studies, 41(4), 491-516. https://doi.org/10.1080/03066150.2014.918958

Ministerstvo sel'skogo khoziaistva Rossiiskoi Federatsii. (2019). O sostoianii sel'skikh territorii v Rossiiskoi Federatsii v 2017 godu: ezhegodnyi doklad po resul 'tatam monitoringa. Moscow: Ministry of Agriculture.

Minsel'khoz. (2020a). Do 2025 goda v Rossii planiruetsia vvesti v oborot $4 \mathrm{mln}$ ga neispol'zuemoi pashni. Retrieved June 4, 2020 from http://mcx.ru/press-service/news/do-2025-goda-v-rossii-planiruetsya-vvestiv-oborot-4-mln-ga-neispolzuemoy-pashni/.

Minsel'khoz. (2020b). S nachala goda tempy obnovleniia parka sel'skokhoziaistvennoi tekhniki uvelichilis'na 20\%. Retrieved December 11, 2020 from https://kvedomosti.ru/news/https-mcx-gov-ru-press-service-news-snachala-goda-tempy-obnovleniya-parka-selskokhozyaystvennoy-tekhniki-uvelichilis-na-20.html

Oppenheimer, M. (2020). As the World Burns. Foreign Affairs, 99(6), 34-41.

Radio Free Europe/Radio Liberty. (2020). Russian PM Approves National Action Plan on Climate Change. Retrieved January 6, 2020 from https://www.rferl.org/a/russian-pm-approves-national-action-plan-onclimate-change/30362756.html?ltflags=mailer

Rosstat. (2018). Itogi Vserossiiskoi sel'skokhoziaistvennoi perepisi 2016 goda. Tom 2. Chislo ob'ektov Vserossiiskoi sel'skokhoziaistvennoi perepisi 2016 goda. Trudovye resursy i ik kharakteristika. Moscow: Rosstat.

Rosstat. (2019). Regiony Rossii. Sotsial'no-ekonomicheskie pokazateli. Moscow: Rosstat.

Rosstat. (2020). Sotsial'no-ekonomicheske indikatory bednosti v 2013-2019 gg. Moscow: Rosstat.

Russia is Warming Disproportionately Fast, Environment Ministry Says. (2019). The Moscow Times. Retrieved September 4, 2019 from www.themoscowtimes.com.

Sachs, J. D. (2015). The Age of Sustainable Development. New York: Columbia University Press. 
Saul, J. (2020). As Arctic ice melts, polluting ships stream into polar waters. Retrieved August 28, 2020 from https://www.reuters.com/article/us-climate-change-arctic-shipping-analys/as-arctic-ice-melts-pollutingships-stream-into-polar-waters-idUSKBN25O0L8

Savage, L. Ch. (2019). How Russia and China are preparing to exploit a warming planet. Politico.com. Retrieved August 29, 2019 from https://www.politico.com/story/2019/08/29/russia-china-climate-change-1691698.

Shea, N. (2019). Scenes from the new Cold War unfolding at the top of the world. Retrieved May 8, 2019 from https:/www.nationalgeographic.com/environment/2018/10/new-cold-war-brews-as-arctic-ice-melts/

Shokurova, E. (2020a). Minsel'khoz peredast subsidii na dal'nevostochnye teplitsy Minvostokrazvitiia. Retrieved September 22, from https://www.agroinvestor.ru/regions/news/34429-minselkhoz-peredast-subsidii-nadalnevostochnye-teplitsy-monvostokrazvitiya/.

Shokurova, E. (2020b). Kvota na eksport zerna mozhet stat' tarifnoi. Retrieved December 14, 2020 from https://www.agroinvestor.ru/markets/news/34985-kvota-na-eksport-zerna-mozhet-stat-tarifnoy/.

Sobolev, O. S. (2020a). Agrarnoe proizvodstvo, prodovol'stvennye tseny i klimat v 2019 godu. Ekonomika sel'skhokhoziaistvennykh i pererabatyvaiushchikh predpriiatii, 3, 64-69.

Sobolev, O. S. (2020b). Klimaticheskie izmeniia v Rossii, agrarnye tseny i proizvodstvo v 2-om kvartale 2020 goda. Ekonomika sel'skhokhoziaistvennykh i pererabatyvaiushchikh predpriiatii, 9, 84-89.

Stern, N. (2007). The Economics of Climate Change. The Stern Review. Cambridge, UK: Cambridge University Press.

Svetlov, N. M., Siptits, S. O., Romanenko, I. A., \& Evdokimova, N. E. (2019). The Effect of Climate Change on the Location of Branches of Agriculture in Russia. Studies on Russian Economic Development, 30(4), 406418.

TASS. (2020). Pravitel 'stvo poruchilo Minsel 'khozu raspredelit'kvotu na eksport zerna iz RF. Retrieved December 16, 2020 from https://agrovesti.net/news/indst/pravitelstvo-poruchilo-minselkhozu-raspredelit-kvotu-naeksport-zerna-iz-rf-do-9-fevralya.html.

United Nations. (2019). World Population Prospects 2019. Retrieved from https://population.un.org/wpp/

Uzun, V., \& Shagaida, N. (2020). Razvitie sel'skogo khoziaistva: ot krupnogo importera do eksportera. In V. S. Gurevich, A. V. Kolesnikkov, A. L. Kudrin, V. A. May, A. D. Radygin, \& S. G. Sinel'nikov-Murylev (Eds.), Ekonomicheskaia politika Rossii: turbulentnoe desiatiletie 2008-2018 (pp. 407-432). Moscow: Delo.

Wegren, S. K. (2011). Food Security and Russia's 2010 Drought. Eurasian Geography and Economics, 52(1), 140156. https://doi.org/10.2747/1539-7216.52.1.140

Wegren, S. K., Nikulin, A., \& Trotsuk, I. (2021). Russia 's Food Revolution: The Transformation of the Food System. London and New York: Routledge Publishers.

\section{Copyrights}

Copyright for this article is retained by the author(s), with first publication rights granted to the journal.

This is an open-access article distributed under the terms and conditions of the Creative Commons Attribution license (http://creativecommons.org/licenses/by/4.0/). 